\begin{tabular}{|l|l|l|l|l|}
\hline Cuadernos de Investigación Geográfica & 2001 & N$^{\circ} 27$ & pp. 179-191 & ISSN 0211-6820 \\
\hline
\end{tabular}

(c) Universidad de La Rioja

\title{
EL NIÑO DRIVEN CLIMATE VARIABILITY AND DRAINAGE ANOMALIES IN PATAGONIAN REGION, ARGENTINA
}

\author{
OLGAE. SCARPATI ${ }^{(1,2)}$ \\ LILIANASPESCHA ${ }^{(3)}$ \\ MARÍAJ. FIORITI ${ }^{(4)}$ \\ ALBERTO D. CAPRIOLO ${ }^{(1)}$
}

(1) National Council of Scientific and Technical Research

(2) Geography Department, Humanities and Education Sciences Faculty, La Plata National University

(3) Faculty of Agronomy, Buenos Aires University

(4) Water Resources Sub Secretary, Serrano 669 (1414) Buenos Aires, Argentina e-mail: olga@mpero.cyt.edu.ar

ABSTRACT: Forecasting of interannual and seasonal variability of hydrological processes is very important when planification of water resources is involved.The hydrological cycle and the climate system are intimately linked, and the knowledge of the atmospheric general circula tion disturbances allows the mentioned forecast. It is increasingly clear that hydrological variability can be interpreted in terms of large-scale climatic anomalies-such as those associated with El Niño/Southern Oscillation (ENSO), and that there are strong relationships between hydro logical anomalies in different parts of the world. Environmental and human characteristics of Patagonian region also contribute to its vulnerability to changes in water availability. Important characteristics are large demand for water supply, extensive development in floodplains, vulnerable groundwater supplies, water-quality problems, dependence on rain fed agriculture, and extensive dependence on hydroelectricity.

Regions where water is already scarce during part or along the whole year are especially vulnerable to the disruption of supply caused by such cli matic variability as prolonged or intense droughts.

This paper describes the relationship between ENSO and river discharges of several Patagonian basins. The period with the highest discharge was selected and the accumulated anomalies of the river discharges were used as hydrological variable. The indexes considered were the sea surface temperature (SST) in the Pacific Ocean as a function of El Niño3 $\left(90^{\circ} \mathrm{W}\right.$ $\left.180^{\circ} \mathrm{W} ; 5^{\circ} \mathrm{N}-5^{\circ} \mathrm{S}\right)$ on the Tropical Pacific Ocean, and the Multivariate ENSO Index (MEI). The results were evaluated with a simple linear regres sion model. They showed a relationship between ENSO (as function of SST) and annual discharges, while MEI index has no significant results. 
RESUMEN: La predicción de la variabilidad interanual y estacional de los procesos hidrológicos es muy importante cuando está en cuestión la planificación de los recursos hídricos. El ciclo hidrológico y el sistema cli mático están íntimamente relacionados, y el conocimiento de las pertur baciones de la circulación general atmosférica facilita la citada predic ción. Está cada vez más claro que la variabilidad hidrológica puede inter pretarse en términos de anomalías climáticas a gran escala, como las aso ciadas con El Niño/Southern Oscillation (ENSO), y que existen fuertes relaciones entre las anomalías hidrológicas en diferentes partes del mundo. Las características ambientales y humanas de la Patagonia contribuyen a su vulnerabilidad frente a cambios en la disponibilidad de agua.: gran demanda de agua, amplio desarrollo de llanuras aluviales, recursos subterráneos vulnerables, problemas de calidad de agua, dependencia de la agricultura de secano y amplia dependencia de la hidroelectricidad. Las áreeas donde el agua es escasa durante parte o todo el año son especialmente vulnerables a la interrupción del abastecimiento de agua causado por la variabilidad climática.

Este trabajo describe las relaciones entre ENSO y los caudales fluvia les en varias cuencas de Patagonia. Se seleccionó el periodo con caudal más elevado y se utilizaron las anomalías de los caudales fluviales como variables hidrológicas. Los índices considerados fueron la temperatuda de la superficie del mar en el Océano Pacífico como una función de El Niño 3, y el Ïndice Multivariable ENSO, Los resultados fueron evaluados con un modelo de regresión lineal simple. Se ha comprobado la existencia de relaciones entre ENSO y los caudales anuales.

Key-words: ENSO, Climate Variability, Water resources, Patagonia.

Palabras clave: ENSO, Variabilidad climática, Recursos hídricos, Patagonia.

\section{Introduction}

Argentine Patagonia, located at southern South America, covers a surface of 700,000 $\mathrm{km}^{2}$. Its climate is cold temperate with moderate thermal amplitude and predominance of westerlies winds. These are very intense and persistent.

The north - south orientation of the Andean mountain chain, the wind circulation from west to east and the rising of humid air masses from the Pacific Ocean cause more abundant precipitation in west Patagonia than in east Patagonia. The heavy rainfalls support forests, peat - bogs and tundra, on organic, wet and acids soils in the piedmont zone. On the other hand, in the central plateau and in the Atlantic riparian plain, a xerophytic steppe has been formed on mineralised soils. To the west, over the Andean mountain chain, the rainfalls are more than $4,000 \mathrm{~mm}$. The precipitation is small close to the Atlantic beach $(200-500 \mathrm{~mm})$ so it indicates a very hard gradient near the mountain.

Close to the mountains the seasonality is mainly winter - autumn, and more than $60 \%$ of the annual rains fall in these seasons.

El Niño/Southern Oscillation (ENSO) is the most important coupled ocean-atmosphere phenomenon to cause global climate variability on interanual time scales. 
Ropelewski and Halpert $(1987,1989)$ investigated global and large - scale regional precipitation patterns and provide a consistent methodology for the definition of the geographical regions and the temporal phase of ENSO - related precipitation. They showed that rainfall variability over the central region of the Andes mountains in Argentina, displays a significant signal associated with ENSO.

Mechoso and Iribarren (1992) studied the relationship of streamflows of La Plata river in southeast South America with the Southern Oscillation. Waylen and Caviades (1990) analysed the annual and seasonal fluctuations of precipitation and streamsflow in the Aconcagua river basin in central Chile.

Berri (1996) summarises the results of recent studies that include ENSO -related rainfall and temperature anomalies in vast regions of South America and Berri and Flamenco (1999) found a statistically significant relationship between the seasonal volume October - March of the Diamante river (central Andes mountains of Argentina) and ENSO.

The statistical properties of annual discharges characteristics in some patagonian rivers are investigated in such a way as to permit the identification of flash - flood- and drought- generation processes and their possible linkage to upset behaviour in the Tropical Pacific. Despite the considerable distance to those regions generally associated with ENSO events, the phenomenon produce marked effects upon the various physical processes that govern the surface hydrometeorology in the studied area.

\section{Objectives}

This work aims to describe the relationship between ENSO and river discharges in several patagonian basins.

The indexes considered were the sea surface temperature (SST) in the Pacific Ocean as a function of El Niño3 $\left(90^{\circ} \mathrm{W}-180^{\circ} \mathrm{W} ; 5^{\circ} \mathrm{N}-5^{\circ} \mathrm{S}\right)$ on the Tropical Pacific Ocean and the Multivariate ENSO Index (MEI).

\section{Material and methods}

The daily discharge data of twenty three gauging stations were provided by the Water Resources Sub - Secretary and they were chosen by their homogeneity and consistency. Their statistical values were calculated using their complete period and considering the water year. In this study the record used for all of them was since 1960 to 2000. The discharge data correspond to the following patagonian basins: Chubut river, Negro river, Santa Cruz river, Futaleufú river, Carrenleufú and Pico river, Senguer and Chico river, Manso and Puelo river, Colorado river and Neuquén river. All of them belong to the Pacific Ocean System with the exception of Santa Cruz river which belong to the Atlantic Ocean System. In Table 1 the gauging stations are listed and their location can be observed in Figure 1. Here we attempt to monitor ENSO based on the Multivariate ENSO Index (MEI) and the Sea Surface Temperature (SST) Niño3 $\left(90^{\circ} \mathrm{W}-180^{\circ} \mathrm{W} ; 5^{\circ} \mathrm{N}-\right.$ $\left.5^{\circ} \mathrm{S}\right)$ on the Tropical Pacific Ocean. 


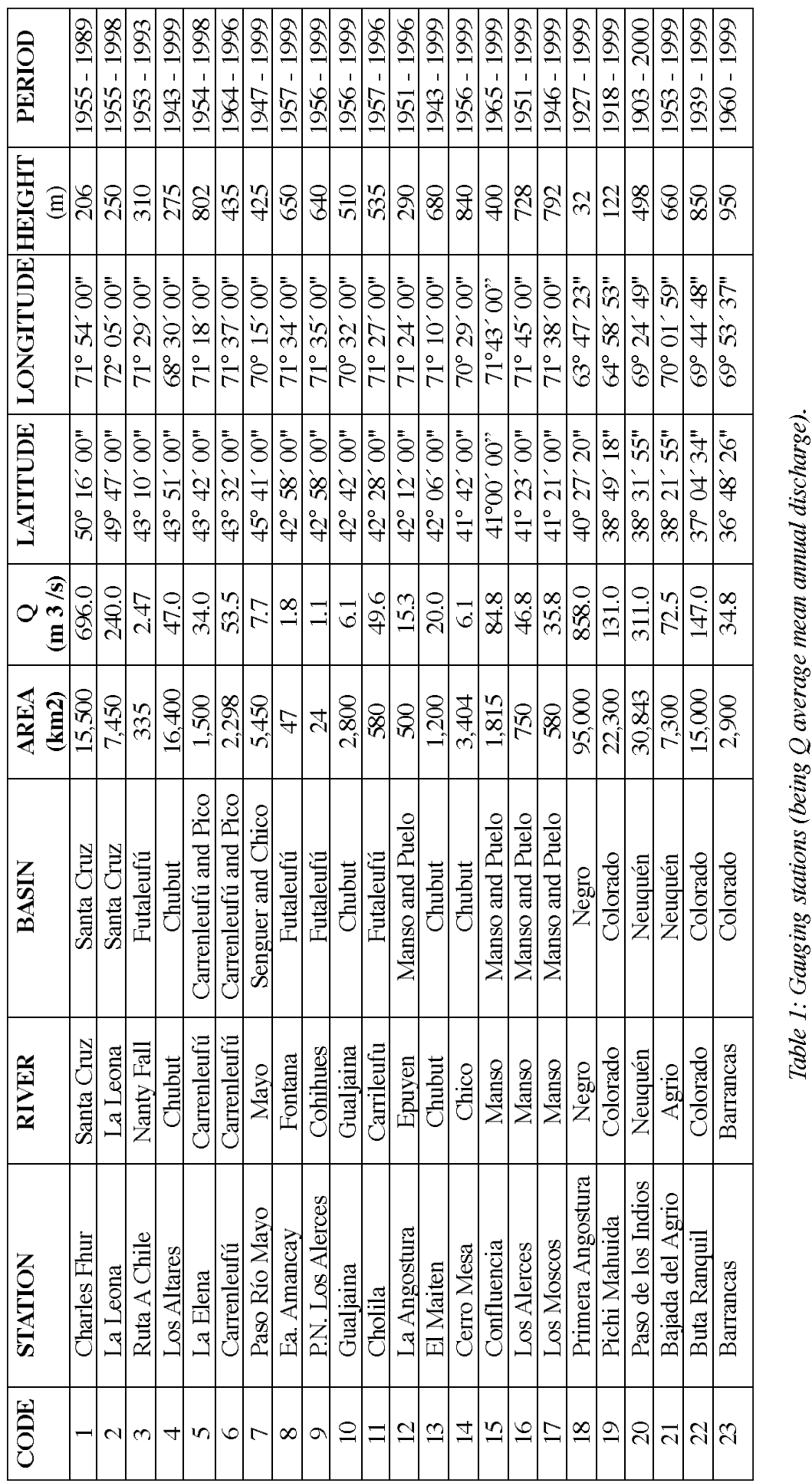




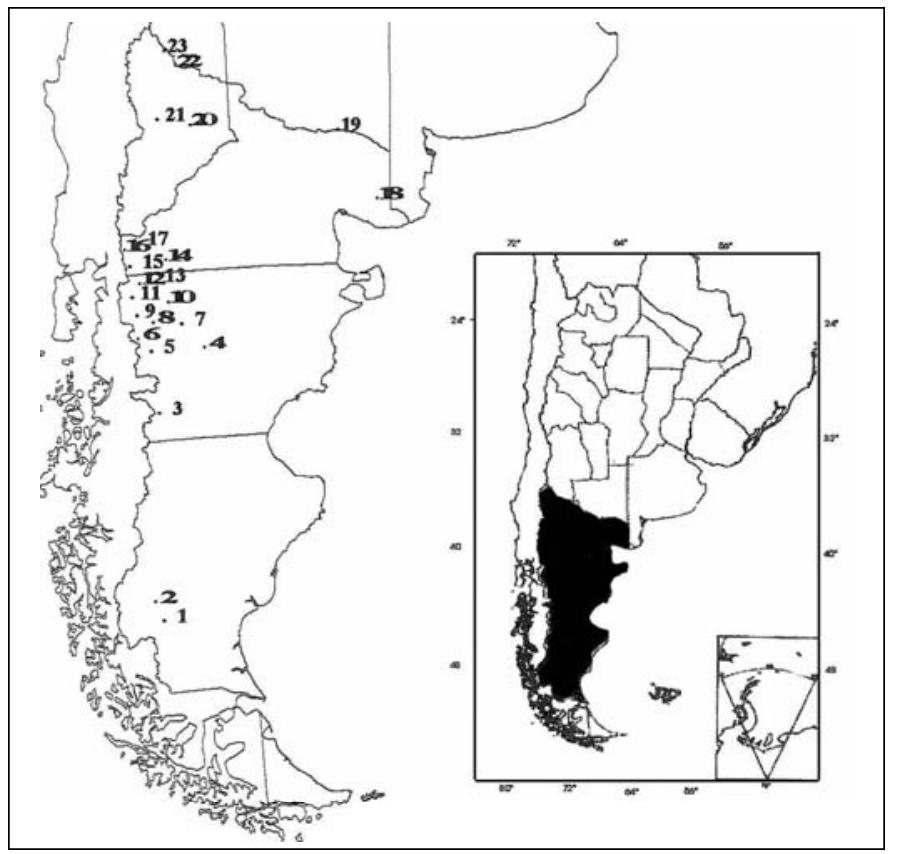

Figure 1: Gauging stations location and the studied area.

1. The Multivariate ENSO Index (MEI) considers six main observed variables over the tropical Pacific. These six variables are: sea-level pressure, zonal and meridional components of the surface wind, sea surface temperature, surface air temperature, and total cloudiness fraction of the sky. Negative values of the MEI represent the cold ENSO phase (La Niña), and the positive ones the warm phase (El Niño).

2. Sea Surface Temperature (SST): El Niño3 $\left(90^{\circ} \mathrm{W}-180^{\circ} \mathrm{W} ; 5^{\circ} \mathrm{N}-5^{\circ} \mathrm{S}\right)$ on the Tropical Pacific Ocean. When average temperature over the region known as El Niño3 $\left(90^{\circ} \mathrm{W}\right.$ $180^{\circ} \mathrm{W} ; 5^{\circ} \mathrm{N}-5^{\circ} \mathrm{S}$ on the Tropical Pacific Ocean) during five months is $0.5^{\circ} \mathrm{C}$ above the normal SST, it represents the warm phase (El Niño). If, on the other hand, the average temperature over El Niño3 Region is $0.5^{\circ} \mathrm{C}$ below the normal El Niño3 index, the cold phase (La Niña) takes place. A neutral event occurs when neither of those conditions are fulfilled.

The indexes are monitored and published regularly in the Climate Diagnostics Bulletin, a monthly publication of the National Center for Environmental Prediction of the U. S. National Oceanic and Atmospheric Administration.

A linear filter was used to remove the tendency of the discharge data and then the obtained anomalies were normalised. The original 1960-2000 annual discharge time series is normalised by subtracting the mean value of the period and dividing by the standard deviation. Similarly, the original monthly indexes (SST and MEI) time series are normalised by subtracting the monthly mean value and dividing by the monthly standard 
deviation. Hereafter the terms annual discharges and indexes will refer to normalised anomalies.

The MEI and the SST were computed separately for each of the twelve sliding bimonthly seasons (Dec/Jan, Jan/Feb, Feb/Mar, Mar/Apr, Apr/May, May/Jun, Jun/Jul, Jul/Aug, Aug/Sep, Sep/Oct, Oct/Nov, Nov/Dec).

We correlated the annual discharges with the two indexes, and they were considered significant if they were higher than 0.25 , which means a significance of $a=0.95$ of $t$ (Student).

\section{Results}

In Table 1 it can be seen the different characteristics of the studied rivers. For example, Primera Angostura has $858 \mathrm{~m}^{3} / \mathrm{s}$ of mean annual discharge and an area of 95,000 $\mathrm{km}^{2}$, and P. N. Los Alerces with $1.14 \mathrm{~m}^{3} / \mathrm{s}$ and $24 \mathrm{~km}^{2}$.

The hydrological year starts in April for nineteen gauging stations, after the summer snowmelt. The hydrological year of the Colorado river starts in July and two rivers, (La Leona and Santa Cruz), both of them in the Santa Cruz river basin, start in September after the winter rains.

Figure 2 shows the discharge patterns of four gauging stations: Charles Fhur, Confluencia, Primera Angostura and Pichi Mahuida. It can be seen the different mean monthly discharge. The regime of the Santa Cruz river (Charles Fhur) differs from the others studied rivers. Its maximum discharge corresponds to March and the minimum to September. This particular behaviour is due to the large two lakes in the head of its basin. Manso (Confluencia) and Negro (Primera Angostura) rivers have pluvio - nival river regime, during the season from October to March, when the precipitation is small, they are fed by the snowmelt. From April to September they are fed by both precipitation and snowfall. Colorado river (Pichi Mahuida) responds to the snowmelt of Andean Mountain Chain with a big flash flood at the beginning of the spring (GAEA, 1975).

As indicated by Chow (1964), the correlation coefficient is the statistical parameter most commonly used for measuring the degree of association between two linearly dependent variables and it was used in this paper.

Table 2 shows the correlation coefficients obtained from the relationship between the discharges and the MEI index. It can be seen that only five correlation coefficients are significant $\mathrm{a}=0.95$ of $\mathrm{t}$ (Student), while Table 3 allows to observe the correlation coefficients obtained from the relationship between the discharges and the SST index. Fifty nine correlation coefficients are significant $\mathrm{a}=0.95$ of $\mathrm{t}$ (Student).

Bajada del Agrio, Buta Ranquil, Barrancas, Paso de los Indios and Pichi Mahuida are the gauging stations that present six months or more with significant correlation coefficients from winter to summer (June - July to December). All these stations belong to the Neuquén and Colorado basins, situated in north Patagonia. On the other hand, Charles Fhur presents significant correlation coefficient in autumn and winter (April to 
El Niño driven climate variability and dainage anomalies in Patagonian region, Argentina
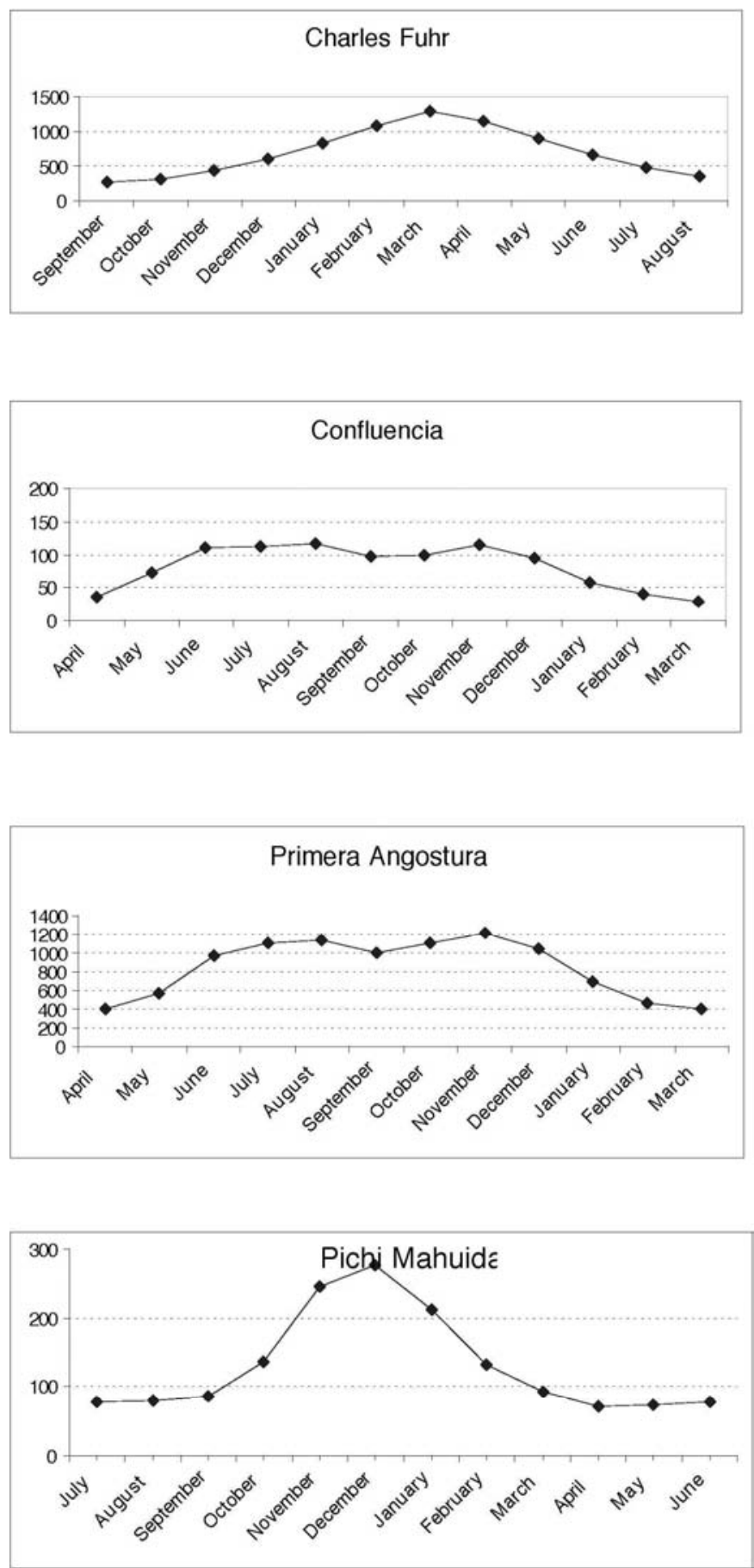

Figure 2: Discharge ( $m 3 s$-1) patterns of the rivers Santa Cruz, (Charles Fhur), Manso (Confluencia), Negro (Primera Angostura) and Colorado (Pichi Mahuida). 
Olga E. Scarpati, Liliana Spescha, María J. Fioriti \& Alberto D. Capriolo

Table 2: Correlation coefficients between the discharges and the MEI index.

\begin{tabular}{|c|c|c|c|c|c|c|c|c|c|c|c|c|}
\hline ing stations & $\mathbf{J}$ & $\mathbf{F}$ & M & $\mathbf{A}$ & M & $\mathbf{J}$ & $\mathbf{J}$ & $\mathbf{A}$ & $\mathbf{S}$ & $\mathbf{O}$ & $\mathbf{N}$ & D \\
\hline Charles Fhur & 0,09 & 0,06 & 0,04 & $-0,01$ & $-0,11$ & $-0,06$ & 0,00 & 0,03 & 0,05 & 0,04 & 0,08 & 0,11 \\
\hline La Leona & 0,11 & 0,07 & 0,08 & 0,06 & $-0,05$ & $-0,01$ & 0,02 & 0,03 & 0,02 & 0,00 & 0,04 & 0,01 \\
\hline Ruta A Chile & $-0,17$ & $-0,14$ & $-0,14$ & $-0,09$ & $-0,05$ & $-0,03$ & 0,01 & $-0,02$ & $-0,01$ & $-0,05$ & $-0,06$ & $-0,01$ \\
\hline Los Altares & 0,03 & 0,07 & 0,09 & 0,14 & 0,13 & 0,11 & 0,11 & 0,05 & 0,06 & 0,09 & 0,05 & 0,06 \\
\hline La Elena & $-0,14$ & $-0,11$ & $-0,17$ & $-0,15$ & $-0,10$ & $-0,04$ & $-0,04$ & $-0,06$ & $-0,01$ & 0,02 & 0,00 & 0,00 \\
\hline Carrenleufu & $-0,21$ & $-0,17$ & $-0,18$ & $-0,15$ & $-0,08$ & $-0,03$ & $-0,03$ & $-0,04$ & 0,02 & 0,10 & 0,07 & 0,06 \\
\hline Paso Rio Mayo & $\underline{-0,30}$ & $\underline{-0,26}$ & $-0,23$ & $-0,24$ & $\underline{-0,25}$ & $-0,22$ & $-0,19$ & $-0,20$ & $-0,19$ & $-0,15$ & $-0,16$ & $-0,17$ \\
\hline Ea. Amancay & $-0,03$ & $-0,05$ & $-0,08$ & $-0,05$ & 0,01 & 0,03 & 0,02 & $-0,01$ & 0,05 & 0,10 & 0,08 & 0,08 \\
\hline P.N. Los Alerces & 0,04 & 0,07 & 0,04 & 0,11 & 0,18 & 0,12 & 0,06 & 0,02 & 0,02 & 0,05 & 0,05 & 0,04 \\
\hline Gualjaina & $-0,01$ & 0,03 & 0,06 & 0,13 & 0,10 & 0,08 & 0,10 & 0,05 & 0,09 & 0,11 & 0,05 & 0,07 \\
\hline Cholila & $-0,09$ & $-0,06$ & $-0,09$ & $-0,07$ & $-0,07$ & $-0,05$ & $-0,06$ & $-0,06$ & 0,01 & 0,05 & 0,03 & 0,03 \\
\hline La Angostura & $-0,07$ & $-0,08$ & $-0,13$ & $-0,08$ & $-0,05$ & $-0,03$ & $-0,03$ & $-0,03$ & 0,02 & 0,11 & 0,10 & 0,08 \\
\hline El Maiten & $-0,10$ & $-0,07$ & $-0,09$ & $-0,05$ & $-0,02$ & $-0,08$ & $-0,07$ & $-0,11$ & $-0,05$ & $-0,03$ & $-0,07$ & $-0,02$ \\
\hline Cerro Mesa & 0,15 & 0,19 & 0,22 & 0,24 & 0,18 & 0,19 & 0,20 & 0,14 & 0,13 & 0,12 & 0,09 & 0,10 \\
\hline Confluencia & 0,02 & 0,05 & 0,02 & 0,02 & $-0,02$ & $-0,04$ & $-0,04$ & $-0,08$ & $-0,04$ & 0,05 & 0,02 & 0,03 \\
\hline Los Alerces & $-0,03$ & 0,00 & $-0,01$ & 0,03 & 0,00 & $-0,04$ & $-0,07$ & $-0,11$ & $-0,07$ & 0,01 & $-0,01$ & $-0,02$ \\
\hline Los Moscos & $-0,06$ & $-0,04$ & $-0,06$ & $-0,06$ & $-0,13$ & $-0,15$ & $-0,14$ & $-0,18$ & $-0,14$ & $-0,05$ & $-0,07$ & $-0,06$ \\
\hline Primera Angostura & 0,16 & 0,20 & 0,21 & 0,23 & 0,17 & 0,20 & 0,20 & 0,19 & 0,24 & $\underline{0,29}$ & $\underline{0,25}$ & 0,23 \\
\hline Pichi Mahuida & $-0,1$ & 0,0 & 0,0 & 0,0 & 0,0 & 0,0 & 0,1 & 0,1 & 0,1 & 0,1 & 0,1 & 0,1 \\
\hline Paso de los Indios & $-0,08$ & $-0,04$ & $-0,04$ & $-0,03$ & $-0,09$ & $-0,13$ & $-0,12$ & $-0,15$ & $-0,11$ & $-0,06$ & $-0,11$ & $-0,04$ \\
\hline Bajada del Agrio & $-0,04$ & $-0,01$ & 0,00 & 0,02 & $-0,06$ & $-0,12$ & $-0,11$ & $-0,16$ & $-0,11$ & $-0,06$ & $-0,10$ & $-0,05$ \\
\hline Buta Ranquil & $-0,11$ & $-0,07$ & $-0,04$ & $-0,04$ & $-0,12$ & $-0,12$ & $-0,06$ & $-0,08$ & $-0,05$ & $-0,01$ & $-0,03$ & 0,01 \\
\hline Barrancas & $-0,02$ & 0,03 & 0,07 & 0,07 & $-0,02$ & $-0,04$ & 0,02 & 0,01 & 0,07 & 0,14 & 0,13 & 0,16 \\
\hline
\end{tabular}

September). In this river, we have to consider that it is located in the south of Patagonia and is that the only one belonging to the Atlantic Ocean system.

The distribution of the annual discharges for Buta Ranquil, Confluencia and Charles Fhur can be seen in Figures 3, 4 and 5 respectively. They where chosen by their high correlation coefficients with the SST index and their geographical location.

Figures 6, 7 and 8 show the correlation obtained between the SST and the discharge anomalies for the Colorado river basin in northern Patagonia, Manso and Puelo river

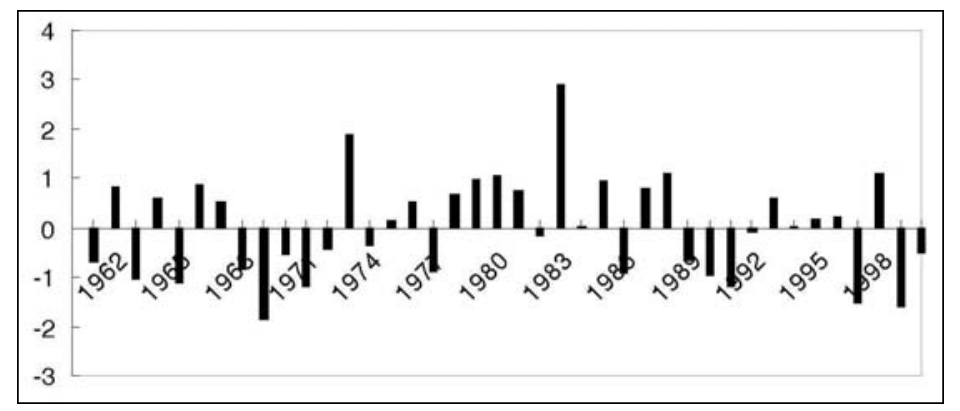

Figure 3: Mean annual discharge anomalies in the Colorado river in Buta Ranquil. 
Table 3: Correlation coefficients between the discharges and the Niño3 index.

\begin{tabular}{|c|c|c|c|c|c|c|c|c|c|c|c|c|}
\hline Gauging stations & $\mathbf{J}$ & $\mathbf{F}$ & M & $\mathbf{A}$ & M & $\mathbf{J}$ & $\mathbf{J}$ & $\mathbf{A}$ & $\mathbf{S}$ & $\mathbf{O}$ & $\mathbf{N}$ & D \\
\hline Charles Fhur & 0.21 & $\underline{0.33}$ & 0.22 & $\underline{0.32}$ & $\underline{0.37}$ & $\underline{0.38}$ & $\underline{0.36}$ & $\underline{0.33}$ & $\underline{0.35}$ & 0.24 & 0.23 & 0.16 \\
\hline La Leona & 0.13 & 0.34 & 0.15 & 0.23 & 0.31 & 0.29 & 0.23 & 0.23 & 0.23 & 0.14 & 0.21 & 0.15 \\
\hline Ruta A Chile & -0.08 & -0.10 & -0.03 & 0.01 & -0.02 & 0.05 & 0.06 & 0.07 & 0.00 & 0.03 & 0.06 & 0.08 \\
\hline Los Altares & -0.06 & -0.14 & -0.07 & 0.04 & 0.04 & 0.15 & 0.18 & 0.15 & 0.21 & $\underline{0.28}$ & $\underline{0.36}$ & $\underline{0.31}$ \\
\hline La Elena & -0.10 & -0.26 & -0.19 & -0.16 & -0.16 & -0.07 & -0.09 & -0.10 & -0.10 & 0.04 & 0.00 & 0.02 \\
\hline Carrenleufu & -0.13 & -0.19 & -0.21 & -0.17 & -0.13 & 0.01 & -0.03 & -0.05 & -0.01 & 0.11 & 0.10 & 0.10 \\
\hline Paso Rio Mayo & -0.14 & -0.11 & -0.16 & -0.19 & -0.10 & -0.06 & 0.01 & 0.08 & 0.06 & 0.01 & 0.11 & 0.07 \\
\hline Ea. Amancay & -0.04 & -0.10 & -0.13 & -0.08 & -0.13 & -0.06 & -0.12 & -0.16 & -0.09 & 0.02 & 0.02 & 0.05 \\
\hline P.N. Los Alerces & $\underline{-0.26}$ & -0.27 & -0.20 & -0.05 & -0.05 & 0.01 & 0.02 & -0.03 & -0.01 & 0.07 & 0.12 & 0.09 \\
\hline Gualjaina & -0.06 & -0.18 & -0.21 & -0.11 & -0.14 & -0.05 & -0.01 & -0.05 & 0.01 & 0.14 & 0.23 & 0.19 \\
\hline Cholila & -0.07 & -0.16 & -0.11 & -0.04 & -0.08 & 0.03 & -0.01 & -0.06 & -0.01 & 0.16 & 0.13 & 0.15 \\
\hline La Angostura & -0.08 & -0.09 & -0.12 & 0.01 & -0.03 & 0.08 & 0.08 & 0.02 & 0.07 & 0.22 & 0.24 & 0.24 \\
\hline El Maiten & -0.14 & -0.18 & -0.05 & 0.05 & 0.00 & 0.13 & 0.16 & 0.08 & 0.08 & 0.16 & 0.22 & 0.22 \\
\hline Cerro Mesa & 0.05 & -0.08 & 0.04 & 0.12 & 0.16 & 0.18 & 0.20 & 0.20 & 0.23 & $\underline{0.29}$ & $\underline{0.38}$ & $\underline{0.38}$ \\
\hline Confluencia & -0.21 & -0.22 & -0.17 & -0.07 & -0.02 & 0.11 & 0.10 & 0.09 & 0.16 & $\underline{0.27}$ & $\underline{0.37}$ & $\underline{0.32}$ \\
\hline Los Alerces & -0.24 & -0.30 & -0.20 & -0.06 & -0.08 & 0.04 & 0.06 & 0.04 & 0.10 & $\underline{0.26}$ & $\underline{0.32}$ & $\underline{0.30}$ \\
\hline Los Moscos & $\underline{-0.25}$ & $\underline{-0.32}$ & -0.17 & -0.06 & -0.07 & 0.07 & 0.10 & 0.10 & 0.13 & $\underline{0.26}$ & $\underline{0.34}$ & $\underline{0.31}$ \\
\hline Primera Angostura & 0.03 & -0.07 & -0.07 & 0.05 & 0.05 & 0.08 & 0.05 & 0.02 & 0.14 & 0.24 & $\underline{0.32}$ & 0.27 \\
\hline Pichi Mahuida & 0.11 & 0.08 & 0.10 & 0.18 & 0.19 & $\underline{0.25}$ & $\underline{0.30}$ & $\underline{0.31}$ & $\underline{0.33}$ & $\underline{0.41}$ & $\underline{0.54}$ & $\underline{0.46}$ \\
\hline Paso de los Indios & -0.06 & 0.01 & 0.10 & 0.16 & 0.18 & $\underline{0.26}$ & $\underline{0.29}$ & $\underline{0.33}$ & $\underline{0.31}$ & $\underline{0.40}$ & $\underline{0.51}$ & $\underline{0.45}$ \\
\hline Bajada del Agrio & -0.14 & -0.08 & 0.01 & 0.08 & 0.11 & 0.23 & $\underline{0.29}$ & $\underline{0.32}$ & $\underline{0.35}$ & $\underline{\mathbf{0 . 4 3}}$ & $\underline{0.55}$ & $\underline{0.50}$ \\
\hline Buta Ranquil & 0.02 & 0.07 & 0.08 & 0.17 & 0.21 & $\underline{\mathbf{0 . 3 0}}$ & $\underline{0.37}$ & $\underline{0.41}$ & $\underline{0.42}$ & $\underline{\mathbf{0 . 5 2}}$ & $\underline{0.66}$ & $\underline{0.58}$ \\
\hline Barrancas & 0.06 & 0.01 & 0.02 & 0.11 & 0.19 & 0.27 & $\underline{0.30}$ & $\underline{0.30}$ & 0.37 & $\underline{0.44}$ & $\underline{0.59}$ & $\underline{0.51}$ \\
\hline
\end{tabular}

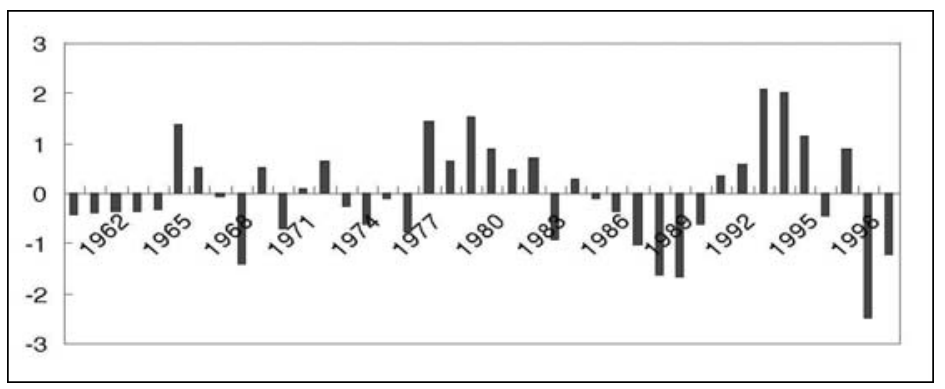

Figure 4: Mean annual discharge anomalies in the Manso river in Confluencia.

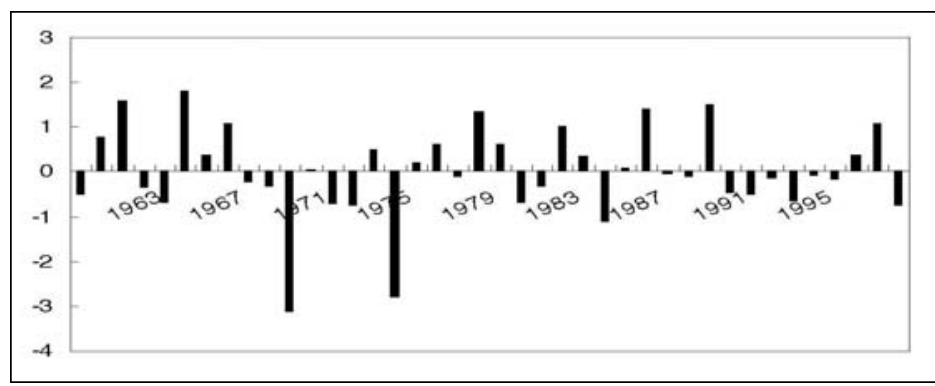

Figure 5: Mean annual discharge anomalies in the Santa Cruz river in Charles Fhur. 


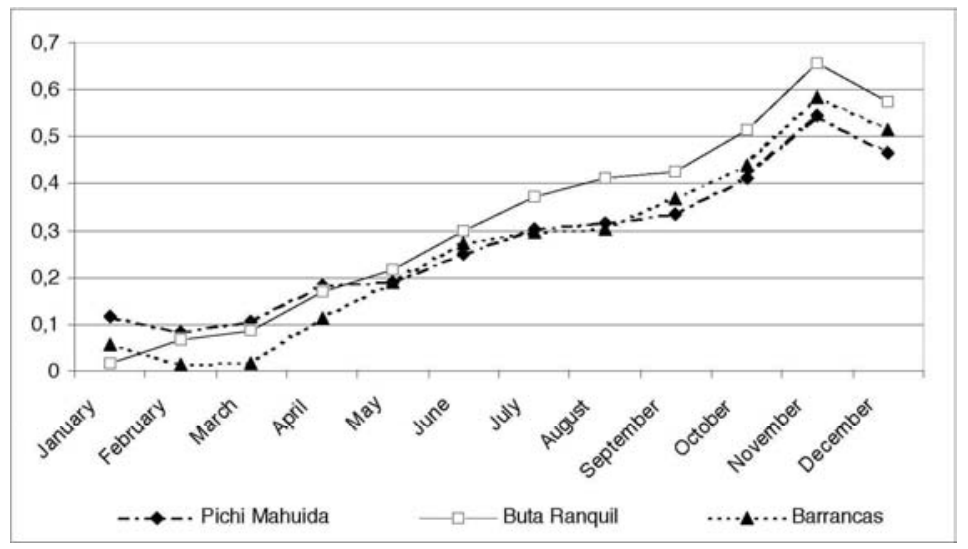

Figure 6: Correlation between the Colorado river discharge (Pichi Mahuida, Buta Ranquil and Barrancas gauging stations) and SST index.

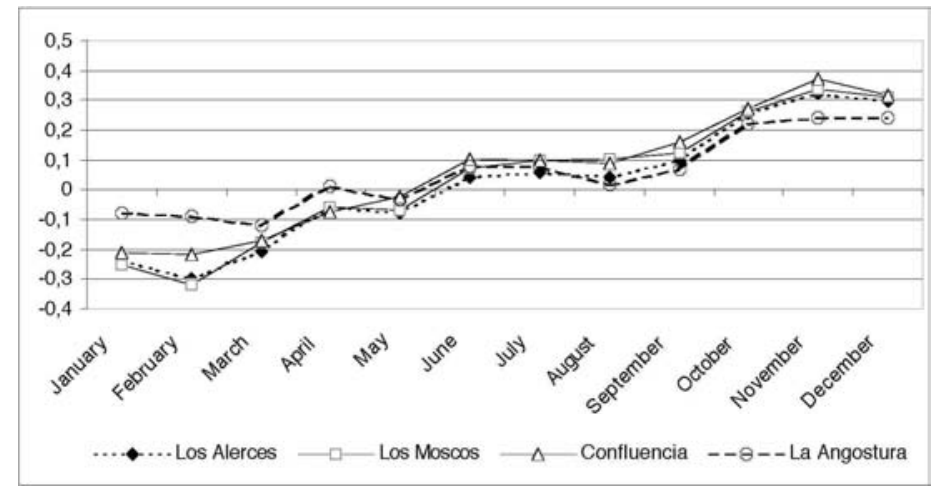

Figure 7: Correlation between the discharge of the Manso and Puelo rivers (Los Alerces, Los Moscoa, Confluencia and La Angostura gauging stations) and SST index.

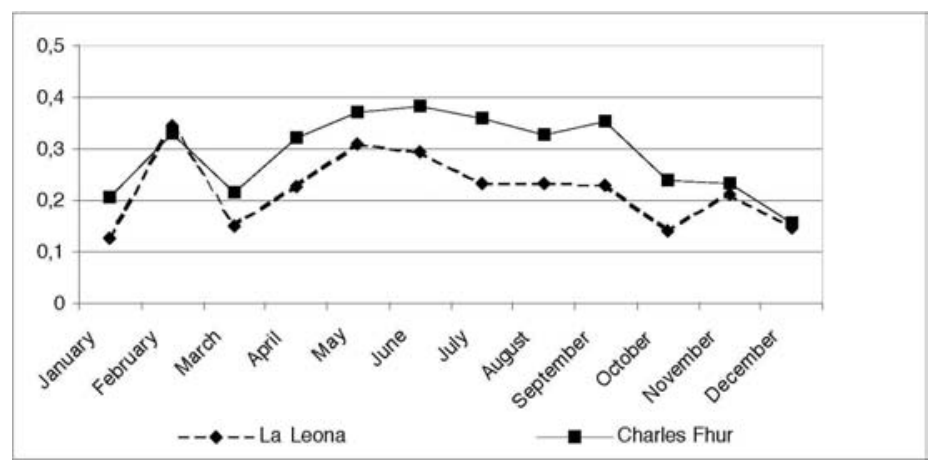

Figure 8: Correlation between the Santa Cruz river discharge (La Leona and Charles Fhur gauging stations) and SST index. 
basin located in the centre of Patagonia and Santa Cruz river basin in southern Patagonia, respectively. Colorado river basin had significant and positive correlation coefficient from June to December. Manso and Puelo river basin present different correlation coefficient during the water year for the four gauging stations. La Angostura has not significant correlation. Los Moscos, Los Alerces and Confluencia have significant correlation three sliding bi-monthly seasons (October/November, November/December and December/January); Los Moscos December/January and January/February too; Los Alerces January/February. The two gauging stations of the Santa Cruz river basin, Charles Fhur and La Leona obtained good correlation for the early months of the year

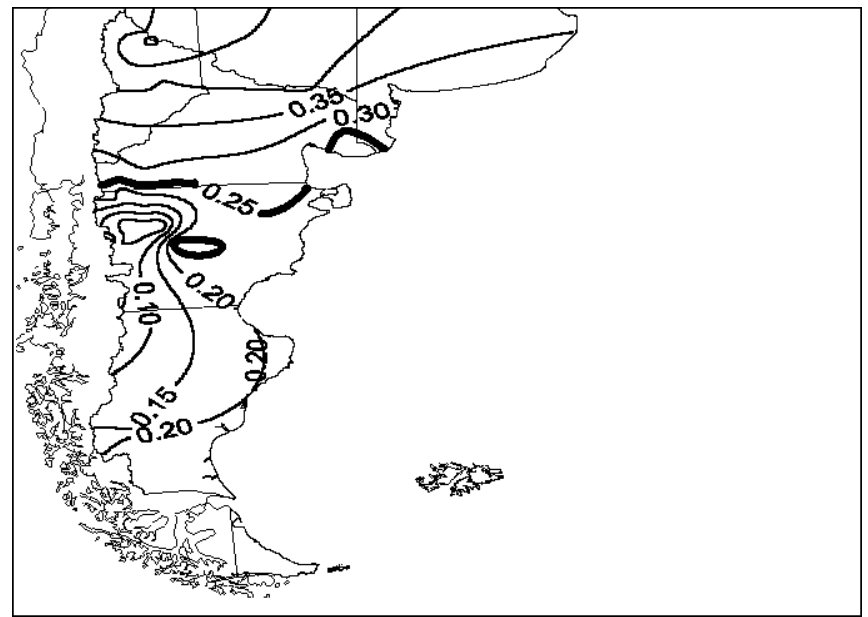

Figure 9: Distribution of the correlation coefficient $r$ between mean annual discharge and October/November SST index (bold characters indicate significance at 95\%).

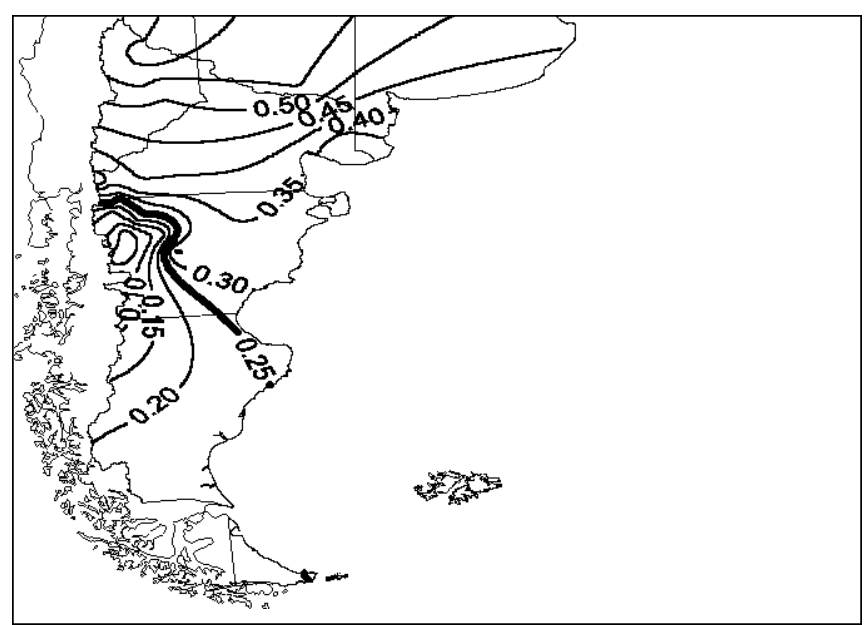

Figure 10: Distribution of the correlation coefficient $r$ between mean annual discharge and November/December SST index (bold characters indicate significance at 95\%). 


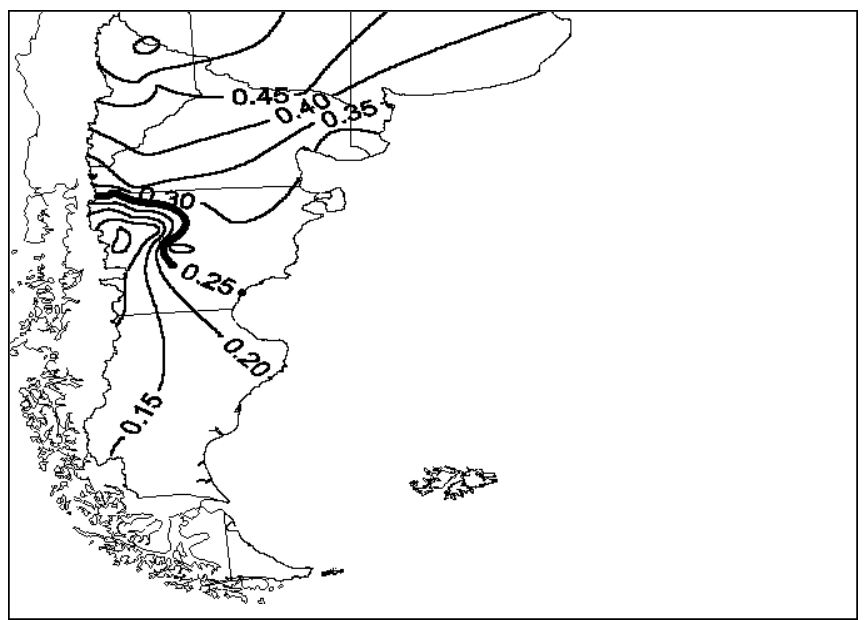

Figure 11: Distribution of the correlation coefficient $r$ between mean annual discharge and December/January SST index (bold characters indicate significance at 95\% ).

and Charles Fhur presents the influence of the SST from January/February, and March/April to September/October, whereas in La Leona for the sliding bi-monthly seasons: April/May and May/June.

In Figures 9, 10 and 11 the distribution of the correlation coefficient obtained for three sliding bi-monthly seasons, October/November, November/December and December/January can be seen. These seasons were chosen because they presented a higher number of significant correlations for all the gauging stations and of them, the highest values correspond to November/December, indicating the strongest ENSO signal. Northern Patagonia presents correlation with the Niño3 index and the discharges from spring and early summer, reaching $r$ values close to 0.60 , which explain $36 \%$ of the annual discharge variance. Central Patagonia and southern Patagonia have no correspondence between SST index and discharges in summer.

\section{Conclusions}

A relationship is found between annual discharge of some patagonian rivers and the SST index observed in the equatorial Pacific Ocean.

The correlation obtained for three sliding bi-monthly seasons, October/November, November/December and December/January were specially chosen because they present significant $r$ values for more gauging stations and their highest values correspond to November/December, indicating the strongest ENSO signal. This signal is more important in northern Patagonia, where $r$ reaches values close to 0.60. MEI index showed no significant correlation with the annual flows. 


\section{References}

Berri, G. (1996). Practical application of statistical modelling of seasonal to interanual climate variability to environmental problems in South America, Ann. Braz. Sci., 68 suppl.: 223-238.

Berri, G. and Flamenco, E. (1999). Seasonal volume forecast in the Diamante river, Argentina, based on observed and predicted Pacific Ocean Sea Surface Temperature. Water Resources Research, 35 (12): 3803-3810.

Chow, V. T. (1964). Handbook of Applied Hydrology. A compendium of water resources Technology. McGraw-Hill, 1418 pp.

GAEA (1975). Sociedad Argentina de Estudios Geográficos. Geografía de la República Argentina. Tomo VII. Segunda Parte. Hidrografía. Sociedad Argentina de Estudios Geográficos, 629 pp., Buenos Aires.

Mechoso, C. R. and Iribarren, G. (1992). Streamflow in south-eastern South America and the Southern Oscillation. J. Clim., 6: 1535-1539.

Ropelewski, C. and Halpert, M. (1987). Global and regional scale precipitation patterns associated with the El Niño/Southern Oscillation. Mon. Weather Rev., 115: 16061626.

Ropelewski, C. and Halpert, M.. (1989). Precipitation patterns associated with the high phase of the Southern Oscillation. J. Clim., 2: 268-284.

Waylen, P. and Caviades, C. (1990). Annual and seasonal fluctuations of precipitation and streamflow in the Aconcagua river basin, Chile. J. Hydrol., 120: 79-102. 